\author{
Katarzyna Kabata, Justyna ŻEBrowska, Dorota Garbera
}

\author{
Zakład Fizjologii Molekularnej Roślin \\ Instytut Biologii Eksperymentalnej \\ Uniwersytet Wrocławski \\ Kanonia 6/8, 50-328 Wrocław \\ E-mail:katarzyna.kabala@uwr.edu.pl
}

\title{
SIARKOWODÓR JAKO CZĄSTECZKA REGULATOROWA W KOMÓRKACH ROŚLINNYCH
}

\section{WSTEP}

Siarkowodór $\left(\mathrm{H}_{2} \mathrm{~S}\right)$ jest bezbarwnym, łatwopalnym gazem o doskonale rozpoznawalnym zapachu zgniłych jaj, kojarzonym zwykle $z$ toksycznym, przypominającym wpływ cyjanowodoru, oddziaływaniem na organizmy żywe (JIN i PEI 2015). Przez człowieka wchłaniany jest $z$ otoczenia drogami oddechowymi i przez skórę, w dużych stężeniach powodując utratę przytomności, a nawet śmierć na skutek niedoboru tlenu w tkankach i narzadach. Siarkowodór blokuje aktywność oksydazy cytochromowej $\mathrm{w}$ mitochondriach, prowadzacc do zaburzeń w wytwarzaniu energii w komórkach (TADEUSIEWICZ i OlAS 2014).

Siarkowodór budowa przypomina cząsteczkę wody, dzięki czemu jest w stanie przenikać przez błony biologiczne w sposób podobny do $\mathrm{H}_{2} \mathrm{O}$, a jego hydrofilowy charakter dodatkowo zwiększa zdolność do przechodzenia przez dwuwarstwę lipidowa (WANG 2012, LI 2013). Z chemicznego punktu widzenia $\mathrm{H}_{2} \mathrm{~S}$ zachowuje się jak słaby kwas. W warunkach fizjologicznych, przy $\mathrm{pH}$ 7,4, jedna trzecia puli siarkowodoru wystepuje w formie niezdysocjowanej, a pozostała część dysocjuje do $\mathrm{H}^{+}$i HS. $\mathrm{HS}^{-}$może dalej ulegać przemianom do $\mathrm{H}^{+}$i $\mathrm{S}^{2-}$ (KABIL i BANERJEE 2010).

$\mathrm{H}_{2} \mathrm{~S}$ od dawna znany jest jako silna fitotoksyna, oddziałująca negatywnie na wzrost i rozwój roślin. Toksyczność $\mathrm{H}_{2} \mathrm{~S}$ zależy od jego stężenia i nasila się $\mathrm{w}$ warunkach stresowych. Wysokie dawki (w zakresie milimolarnym) aplikowane roślinom moga powodować m.in. zmiany nekrotyczne liści i ich utrate, zahamowanie aktywności enzymów oraz spadek pobierania związków mineralnych, np. fosforu (LISJAK i współaut. 2013). Stosunkowo niedawno natomiast zaobserwowano, że w niższych stężeniach $\mathrm{H}_{2} \mathrm{~S}$ działa jako cząsteczka aktywna biologicznie, wywołujaca pozytywne efekty zarówno na procesy wzrostowe roślin, jak i na łagodzenie skutków wywołanych przez czynniki stresowe (HANCOCK i współaut. 2011). Niskie dawki $\mathrm{H}_{2} \mathrm{~S}$ stymuluja wzrost roślin, zwiększaja ich świeżą masę, pobudzają kiełkowanie nasion i powiększanie blaszki liściowej, co sugeruje ogromny potencjał wykorzystania siarkowodoru w rolnictwie (FILIPOVIC i JOVANOVIĆ 2017). Badania ostatnich lat podkreślajac rolę $\mathrm{H}_{2} \mathrm{~S}$ jako sygnału, pełniącego podobna funkcję do dwóch znanych gazotransmiterów, tlenku azotu (NO) i tlenku węgla (CO), zarówno u zwierząt, jak i u roślin (WANG 2002, PAE i współaut. 2009, LISJAK i współaut. 2013).

Badania farmakologiczne prowadzone $u$ ssaków $z$ wykorzystaniem donorów siarkowodoru wykazały istotna rolę tej cząsteczki w funkcjonowaniu układu nerwowego i krwionośnego, poprzez modulowanie aktywności receptorów kwasu N-metylo-D-asparaginowego (NMDA) i wrażliwych na ATP kanałów potasowych $\left(\mathrm{K}_{\mathrm{ATP}}\right)$. Stwierdzono ponadto, że $\mathrm{H}_{2} \mathrm{~S}$ zdolny jest hamować lub stymulować jądrową translokację czynników transkrypcyjnych NF-kB, uczestniczacych w odpowiedzi komórkowej na bodźce zewnętrzne, a także modyfikować aktywność wielu kinaz białkowych (LI i współaut. 2011, KIMURA 2012, TADEUSIEWICZ i OlAS 2014). 


\section{REGULACJA POZIOMU SIARKOWODORU W KOMORKACH}

W środowisku naturalnym siarkowodór powstaje w wyniku aktywności wulkanicznej i podczas rozkładu substancji organicznych, uwalniany jest $z$ przybrzeżnych osadów morskich. Jego powstawanie jest często efektem działalności człowieka, związanej $z$ funkcjonowaniem oczyszczalni ścieków i elektrowni geotermalnych, rolnictwem czy emisja spalin samochodowych. Obecny w srodowisku $\mathrm{H}_{2} \mathrm{~S}$ może być pobierany zarówno przez części nadziemne roślin, jak i korzenie. Jednak aby cząsteczka ta mogła pełnić funkcję wtórnego przekaźnika, w komórkach żywych organizmów musza istnieć endogenne systemy odpowiedzialne za jej biosyntezę i rozkład (WANG 2002, LISJAK i współaut. 2013).

Liczne badania przeprowadzone u ssaków wykazały, że $\mathrm{H}_{2} \mathrm{~S}$ może być generowany przez wiele typów komórek, a jego endogenna zawartość jest znacznie niższa od stężeń wywołujacych efekty toksyczne. W komórkach zwierzęcych zidentyfikowano trzy enzymy odpowiedzialne za produkcję $\mathrm{H}_{2} \mathrm{~S}$. Należa do nich: $\beta$-syntaza cystationiny (CBS) i $\gamma$-liaza cystationiny (CSE), uczestniczace w metabolizmie cysteiny i homocysteiny, oraz transferaza siarkowa 3-merkaptopirogronianu (3-MST), wykorzystująca 3-merkaptopirogronian jako substrat (WANG 2012, KoLLURU i i współaut. 2013). Dodatkowo, w organizmach zwierzecych funkcjonuje nieenzymatyczny szlak generowania siarkowodoru. Obejmuje on między innymi bezpośrednia redukcje glutationu i siarki elementarnej do $\mathrm{H}_{2} \mathrm{~S}$, która zachodzi w obecności zwiazków redukujacych, NADH lub NADPH. Powstały ta droga siarkowodór stanowi jednak niewielka część całkowitego endogennego poziomu $\mathrm{H}_{2} \mathrm{~S}$ (WANG 2002, KIMURA 2012).

W komórkach zwierzęcych funkcjonuja dwa szlaki metaboliczne, których rola jest obniżanie zawartości siarkowodoru. Pierwszy $z$ nich, zachodzacy głównie w mitochondriach, polega na utlenieniu $\mathrm{H}_{2} \mathrm{~S}$ do tiosiarczanu. Reakcja katalizowana jest przez oksydoreduktazę chinonowa. Tiosiarczan dalej ulega przemianom prowadzacym do powstania siarczanów. Drugi mechanizm polega ma metylacji $\mathrm{H}_{2} \mathrm{~S}$ i powstaniu siarczku dimetylu. Reakcja ta zachodzi dzięki S-metylotransferazie tiolowej na terenie cytoplazmy (KIMURA 2012, TADEUSIEWICZ i OLAS 2014).

Poprzez analogie do komórek zwierzecych odkryto, że wytwarzanie $\mathrm{H}_{2} \mathrm{~S}$ przez komórki roślinne w dużej mierze związane jest również $z$ metabolizmem cysteiny. Jednak w przeciwieństwie do zwierząt, nie potwierdzono dotąd możliwości biosyntezy $\mathrm{H}_{2} \mathrm{~S}$ u roślin na drodze nieenzymatycznej. Badania ostat- nich lat dowiodły, że za biosyntezę siarkowodoru odpowiedzialne sa głównie desulfhydrazy, czyli enzymy uczestniczące w degradacji cysteiny (LISJAK i współaut. 2013). Desulfhydrazy sa białkami zależnymi od 5'-fosforanu pirydoksalu (PLP), aktywnej formy pochodnej witaminy B6, stanowiacej grupe prostetyczną enzymów zaangażowanych w metabolizm aminokwasów (PAPENBROCK i współaut. 2007). Wykazano, że poziom aktywności desulfhydraz uczestniczacych w produkcji siarkowodoru może ulegać modyfikacjom w zależności od stanu rozwojowego roślin i zmieniajacych się warunków środowiskowych (LISJAK i współaut. 2013).

Rośliny posiadaja dwa rodzaje desulfhydraz, korzystających $z$ różnych izomerów cysteiny jako substratów. Desulfhydraza L-cysteiny (L-CD) jest odpowiednikiem zwierzęcego enzymu CSE. Katalizuje ona reakcję degradacji L-cysteiny do pirogronianu, amoniaku i $\mathrm{H}_{2} \mathrm{~S}$, powstających w stosunku 1:1:1 (BURANDT i współaut. 2002, SCHMIDT 2005). Desulfhydraza D-cysteiny (D-CD) jest drugim po L-CD enzymem odpowiedzialnym za generowanie $\mathrm{H}_{2} \mathrm{~S}$ u roślin. W wyniku reakcji katalizowanej przez D-CD powstaja takie same produkty, jednak substratem w reakcji jest D-cysteina (PAPENBROCK i współaut. 2007). Aktywność obu desulfhydraz można łatwo oddzielić od siebie, ponieważ oprócz wykorzystywania różnych substratów, wykazuja one odmienne optimum $\mathrm{pH}$ reakcji (dla D-CD pH 8,0, a w przypadku L-CD pH 9,0) oraz różna wrażliwość na inhibitory (kwas aminooksyoctowy, AOA i hydroksyloaminę, HA). Aktywność enzymów $z$ grupy desulfhydraz stwierdzono u różnych gatunków roślin głównie na terenie cytoplazmy, a także w mitochondriach (Ryc. 1) (RIEMENSCHNEIDER i współaut. 2005, WANG 2012, LI 2013, LISJAK i współaut. 2013). U Arabidopsis thaliana zidentyfikowano gen des1, a następnie wyizolowano białko DES1 odpowiedzialne za reakcję desulfhydracji L-cysteiny i generowanie $\mathrm{H}_{2} \mathrm{~S}$ w cytoplazmie (ÁLVAREZ i współaut. 2010). Jest to dotąd jedyna desulfhydraza scharakteryzowana na poziomie molekularnym. Mutanty des1 Arabidopsis stanowia cenne narzędzie wykorzystywane w badaniach szlaków sygnałowych $\mathrm{z}$ udziałem $\mathrm{H}_{2} \mathrm{~S}$.

W komórkach roślinnych $\mathrm{H}_{2} \mathrm{~S}$ może powstawać ponadto $\mathrm{w}$ wyniku reakcji katalizowanych przez reduktazę siarczynowa (SiR) oraz syntazę $\beta$-cyjanoalaniny (CAS). SiR uczestniczy $\mathrm{w}$ procesie asymilacji siarczanów odbywajacym się na terenie chloroplastów. Enzym ten odpowiedzialny jest za redukcję siarczynów do $\mathrm{H}_{2} \mathrm{~S}$ w obecności zredukowanej ferredoksyny jako donora elektronów. CAS funkcjonuje wewnątrz mitochondriów, gdzie przekształca cysteinę i cyjanek do $\mathrm{H}_{2} \mathrm{~S}$ 


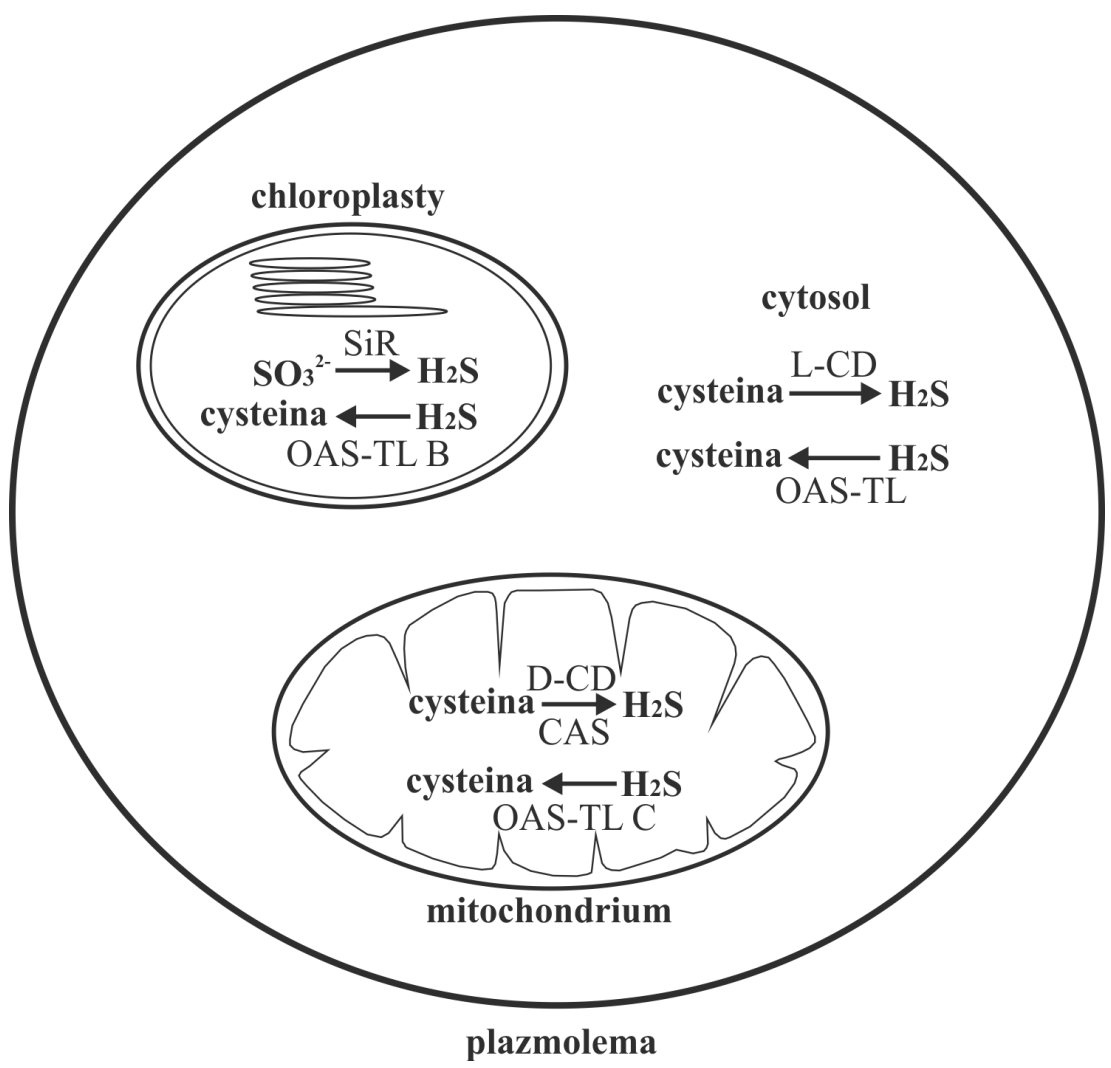

Ryc. 1. Systemy enzymatyczne, zaangażowane w homeostazę $\mathrm{H}_{2} \mathrm{~S}$ w komórkach roślinnych.

Poziom siarkowodoru regulowany jest przez aktywność desulfhydrazy L-cysteiny (L-CD), desulfhydrazy D-cysteiny (D$\mathrm{CD}$ ), reduktazy siarczynowej (SiR), syntazy $\beta$-cyjanoalaniny (CAS) oraz liaz $O$-acetyloserynowo-tiolowych (OAS-TL A, B i C).

i $\beta$-cyjanoalaniny (Ryc. 1) (PAPENBROCK i współaut. 2007, LI 2013). Pomimo posiadania przez rośliny endogennego źródła siarkowodoru w chloroplastach i mitochondriach, obecnie uważa się, że to aktywność desulfhydraz w cytoplazmie i cytosolowa pula $\mathrm{H}_{2} \mathrm{~S}$ decyduja o jego funkcji jako czasteczki sygnałowej. $\mathrm{H}_{2} \mathrm{~S}$ powstajacy w obrębie chloroplastów i mitochondriów prawdopodobnie nie dyfunduje do cytoplazmy, m.in. ze względu na zasadowe $\mathrm{pH}$ panujace w tych kompartmentach (ROMERO i współaut. 2014).

Aktywny poziom $\mathrm{H}_{2} \mathrm{~S}$ w komórkach jest wynikiem nie tylko biosyntezy, ale też przemian metabolicznych. W tkankach roślinnych w procesy degradacji siarkowodoru, czyli obniżanie jego endogennego poziomu, zaangażowane sa liazy O-acetyloserynowo-tiolowe (OAS-TL). Stanowia one ostatni enzym w szlaku asymilacji siarczanów, uczestniczacy w biosyntezie cysteiny. OAS-TL katalizuja reakcje właczania $\mathrm{H}_{2} \mathrm{~S}$ do $\mathrm{O}$ -acetylo-L-seryny (OAS), czemu towarzyszy wytworzenie L-cysteiny i octanu. U A. thaliana zidentyfikowano trzy izoformy tego enzymu, które różnią się lokalizacją w komórce. OAS-TL A zlokalizowane sa w cytoplazmie, podczas gdy OAS-TL B i OAS-TL C występują odpowiednio na terenie plastydów i mitochondriów (Ryc. 1) (BURANDT i współaut. 2002). Poszczególne izoformy różnią się między sobą właściwościami katalitycznymi, głównie powinowactwem do substratów, czyli $\mathrm{H}_{2} \mathrm{~S}$ i OAS (SCHMIDT 2005). ÁlVAREZ i współaut. (2010) zaproponowali, że w komórkach Arabidopsis uwalnianie $\mathrm{H}_{2} \mathrm{~S}$ i jego degradacja $w$ cytosolu (zwiazane $z$ rozkładem $i$ biosynteza cysteiny) koordynowane jest przez aktywność DES1 i OAS-TL A1.

W badaniach dotyczacych roli siarkowodoru w komórkach roślinnych wykorzystywane sa egzogenne generatory tej czasteczki. Podobnie jak u zwierząt, najczęściej stosowanym donorem $\mathrm{H}_{2} \mathrm{~S}$ jest wodorosiarczek sodu (NaHS), łatwo i szybko dysocjujący, który generuje krótkotrwały, silny impuls $\mathrm{H}_{2} \mathrm{~S}$. W ostatnich latach natomiast zwrócono uwage na alternatywne zwiąki, stosowane głównie w badaniach biomedycznych. Należy do nich GYY4137 (morpholin-4-ium-4-methoxyphenyl (morpholino) phosphinodithioate), odpowiedziany za powolne uwalnianie mniejszych dawek $\mathrm{H}_{2} \mathrm{~S}$, co lepiej odzwierciedla warunki fizjologiczne panujace w komórkach (LISJAK i współaut. 2013). 


\section{MOLEKULARNY MECHANIZM} DZIAEANIA SIARKOWODORU

W wyniku badań przeprowadzonych na komórkach ssaczych zaproponowano, że głównym mechanizmem działania $\mathrm{H}_{2} \mathrm{~S}$, decydujacym o jego roli jako cząsteczki sygnalowej, jest potranslacyjna modyfikacja reaktywnych reszt cysteiny $\mathrm{w}$ białkach, nazwana S-sulfhydracja. Siarkowodór przekształca grupy tiolowe (-SH) do mostków nadsiarczkowych (-SSH), prowadzacc do zmian funkcjonalnych białek, analogicznie do reakcji S-nitrozylacji wywoływanej przez NO czy innych oksydacyjnych modyfikacji reszt cysteiny, jak S-glutationylacja (YANG 2014). Efektem S-sulfhydracji białek sa zmiany ich aktywności enzymatycznych, struktury i subkomórkowej lokalizacji. W komórkach zwierzęcych wykazano, że S-sulfhydracja może zarówno aktywować, jak i hamować działanie enzymów (MUSTAFA i współaut. 2009). Módis i współaut. (2016) dowiedli, że $\mathrm{H}_{2} \mathrm{~S}$ indukuje sulfhydrację dwóch reszt cysteiny $\mathrm{w}$ podjednostce a syntazy ATP. Ta modyfikacja odpowiedzialna jest za utrzymywanie enzymu w stanie fizjologicznie aktywnym i funkcje energetyczne mitochondriów.

Stosunkowo niedawno potwierdzono, że S-sulfhydracja $\mathrm{w}$ podobny sposób odwracalnie reguluje funkcjonowanie białek roślinnych (AROCA i współaut. 2015, 2017). Badania przeprowadzone przez AROCA i współaut. (2017) ujawniły, że co najmniej 5\% całego proteomu Arabidopsis podlega S-sulfhydracji. $\mathrm{Na}$ podstawie analiz jakościowych stwierdzono, że S-sulfhydracja jest istotnym elementem wielu podstawowych roślinnych szlaków metabolicznych, jak glikoliza, cykl kwasów trójkarboksylowych, cykl Calvina czy biosynteza skrobi. Mutanty des1 Arabidpsis wykazuja obniżony poziom sulfhydracji wielu bialek. Przykładem sa receptory kwasu abscysynowego (ABA) (AROCA i współaut. 2017). Sugeruje to ważna rolę $\mathrm{H}_{2} \mathrm{~S}$ i indukowanych przez niego modyfikacji $\mathrm{w}$ procesach wzrostu i rozwoju roślin.

Obecnie uważa się, że $\mathrm{H}_{2} \mathrm{~S}$ nie może reagować bezpośrednio $z$ grupami - $\mathrm{SH}$, a sulfhydracja białek jest mechanizmem odpowiedzialnym za redukcję utlenionych reszt cysteiny (FILIPOVIC i JovANović 2017). Takie działanie siarkowodoru zwiększa zdolności antyoksydacyjne cysteiny. W wyniku wzmożonej produkcji reaktywnych form tlenu (ROS) grupy tiolowe białek sa utleniane tworząc kwas sulfenowy (-SOH), który może reagować z $\mathrm{H}_{2} \mathrm{~S}$. Powstały nadsiarczek (-SSH) zapobiega dalszym nieodwracalnym przemianom oksydacyjnym reszt cysteiny do kwasu sulfinowego $\left(-\mathrm{SO}_{2} \mathrm{H}\right)$ i sulfonowego $\left(-\mathrm{SO}_{3} \mathrm{H}\right)$ (FIlipovic i Jovanović 2017). Badania wy- kazały, że reakcja kwasu sulfenowego $\mathrm{z} \mathrm{H}_{2} \mathrm{~S}$ przebiega 600 razy szybciej od reakcji $z$ glutationem (CuEvasAnTA i współaut. 2015), a wzrost S-sulfhydracji białek pojawia sie $\mathrm{w}$ odpowiedzi na stres wywołany przez $\mathrm{H}_{2} \mathrm{O}_{2}$ (WEDMANN i współaut. 2016). Mostki nadsiarczkowe moga w łatwy sposób ulegać redukcji do grup tiolowych przez działanie tioredoksyn, dzięki czemu związany $\mathrm{H}_{2} \mathrm{~S}$ jest uwalniany i może ponownie zostać wykorzystany przez komórkę (WEDMANN i współaut. 2016). Powyższe dane jasno wskazuja na ważna role siarkowodoru $\mathrm{w}$ procesach antyoksydacyjnych i w regulacji stanu redoks reszt cysteiny białek, istotnych $\mathrm{w}$ wielu szlakach biochemicznych.

\section{FUNKCJE SIARKOWODORU W ROŚLINACH}

\section{REGULACJA PROCESÓW WZROSTU I ROZWOJU ROŚLIN PRZEZ $\mathrm{H}_{2} \mathrm{~S}$}

Siarkowodór zaangażowany jest $\mathrm{w}$ wiele procesów fizjologicznych zachodzacych w roślinach. Wykazano, że odgrywa on ważna rolę $\mathrm{w}$ ruchach aparatów szparkowych i fotosyntezie, uczestniczy w regulacji kiełkowania nasion, organogenezy i starzenia roślin (LI i współaut. 2013).

Coraz liczniejsze prace potwierdzaja udział siarkowodoru $\mathrm{w}$ mechanizmach kontrolujacych stan otwarcia aparatów szparkowych, co wiąże się $z$ jego oddziaływaniem $z$ innymi cząsteczkami zaangażowanymi $\mathrm{w}$ ten proces (Li 2013). Należy jednak podkreślić, że badania te dostarczają różnych, często przeciwstawnych wyników. Wykazano, że u A. thaliana i Capsicum annuum $\mathrm{H}_{2} \mathrm{~S}$ pobudza otwieranie aparatów szparkowych na swietle i zapobiega ich zamykaniu $\mathrm{w}$ ciemności, zmniejszajac akumulację NO w komórkach szparkowych. Większość badań natomiast, przeprowadzonych na $A$. thaliana, Vicia faba i Impatiens walleriana, dowiodło, że $\mathrm{H}_{2} \mathrm{~S}$ powoduje zamykanie aparatów szparkowych, uczestnicząc w ścieżce sygnałowej indukowanej przez kwas abscysynowy, co ma szczególne znaczenie w warunkach suszy i zapobiega odwodnieniu tkanek. Wykazano ponadto, że siarkowodór jest istotnym elementem szlaku odpowiedzialnego za zamykanie szparek w odpowiedzi na etylen (GARCía-Mata i LamatTina 2013, Jin i Pei 2016). $\mathrm{H}_{2} \mathrm{~S}$ zdolny jest indukować produkcję $\mathrm{H}_{2} \mathrm{O}_{2}$ $\mathrm{w}$ komórkach szparkowych, głównie przez stymulację oksydazy NADPH, prowadzac do zamykania szparek (LI 2013). Najnowsze badania podkreślają rolę $\mathrm{H}_{2} \mathrm{~S}$ w regulacji aktywności kanałów jonowych funkcjonujących w komórkach szparkowych, w tym kanałów wapniowych, potasowych i anionowych, su- 
gerując, że siarkowodór uczestniczy w zamykaniu szparek poprzez modulowanie przepływu jonów. Stwierdzono także, że $\mathrm{H}_{2} \mathrm{~S}$ aktywuje ekspresję genów i stopień fosforylacji plazmolemowej pompy protonowej, kontrolujacc w ten sposób aktywność antyportera $\mathrm{Na}^{+} / \mathrm{H}^{+}$i utrzymujac odpowiedni stosunek $\mathrm{K}^{+} / \mathrm{Na}^{+} \mathrm{w}$ odpowiedzi na stres solny (JIN i PEI 2016). Potwierdza to, że siarkowodór spełnia ważną rolę w regulacji ruchów szparek podczas zmieniajacych się warunków środowiskowych.

Fotosynteza jest jednym $z$ najważniejszych procesów zachodzacych w komórkach roślinnych, a jej efektywność zależy od wielu czynników, w tym także od funkcjonowania aparatów szparkowych. Egzogenny $\mathrm{H}_{2} \mathrm{~S}$ może podnosić wydajność fotosyntezy poprzez zwiększanie światła szparek oraz wzrost ich zagęszczenia, obniżając jednocześnie intensywność fotorespiracji (DUAN i współaut. 2015). Obserwuje się ponadto podwyższona zawartość chlorofilu w liściach i zwiększona liczbę gran w chloroplastach. $\mathrm{H}_{2} \mathrm{~S}$ stymuluje ekspresję genów i aktywność Rubisco, a także podnosi poziom białka dużej podjednostki enzymu, ponadto aktywuje transkrypcję genów kodujących ferredoksynę i tioredoksyny, w efekcie prowadzac do wzrostu parametrów zarówno fazy jasnej i fazy ciemnej fotosyntezy (CHEN i współaut. 2011). Wyniki wskazuja, że $\mathrm{H}_{2} \mathrm{~S}$ odgrywa istotna rolę $\mathrm{w}$ regulacji fotosyntezy, częściowo poprzez modulowanie ekspresji genów istotnych dla tego procesu i modyfikacje oksydoredukcyjne.

Intensywnie prowadzone w ostatnich latach badania wskazuja, że $\mathrm{H}_{2} \mathrm{~S}$ wymagany jest na różnych etapach wzrostu i rozwoju roślin. Traktowanie niskimi dawkami siarkowodoru stymuluje kiełkowanie nasion i wzrost siewek różnych gatunków roślin, zwiększając biomasę korzeni, łodyg i liści. Wyniki tych badań sugeruja, że obserwowany efekt zwiazany jest $z$ uruchamianiem przez $\mathrm{H}_{2} \mathrm{~S}$ mechanizmów kontrolujących podziały komórkowe, a nie $z$ powiększaniem rozmiarów poszczególnych komórek (DOOLEY i współaut. 2013). Zaobserwowano, że korzystny wpływ $\mathrm{H}_{2} \mathrm{~S}$ na wydajność kiełkowania skorelowany jest ze wzmożona aktywnościa amylazy i enzymów antyoksydacyjnych, a w konsekwencji $z$ obniżonym poziomem peroksydacji lipidów i spadkiem zawartości $\mathrm{H}_{2} \mathrm{O}_{2}$. Siarkowodór promuje kiełkowanie nasion $\mathrm{za}$ równo w warunkach kontrolnych, optymalnych dla tego procesu, jak i stresowych, np. pod wpływem metali ciężkich i zasolenia (LI i współaut. 2013, JIN i PEI 2015).

Organogeneza podlega regulacji przez wiele czynników zarówno środowiskowych, jak i endogennych, $z$ których najlepiej poznanymi sa fitohormony. $\mathrm{W}$ proces powsta- wania korzeni zaangażowane są głównie auksyny (IAA), odpowiedzialne za tworzenie nowego merystemu apikalnego. Stosunkowo niedawno odkryto, że siarkowodór zdolny jest indukować powstawanie korzeni przybyszowych i korzeni bocznych, i stanowi kolejny istotny element ścieżki sygnałowej, w której uczestnicza auksyny i NO (ZHANG i współaut. 2009). Wykazano, że $\mathrm{H}_{2} \mathrm{~S}$ modyfikuje polarny transport auksyn i ich dystrybucję w sposób zależny od cytoszkieletu (F-aktyny), co prowadzi do zmian rozwojowych w korzeniach (JIA i współaut. 2015). Ponadto $\mathrm{H}_{2} \mathrm{~S}$, podobnie jak IAA, pobudza proces organogenezy korzeni, modulując ekspresję genów regulatorowych cyklu komórkowego (FANG i współaut. 2014). Najnowsze badania potwierdzają, że siarkowodór w pierwszej kolejności stymuluje ekspresję genów kodujacych oksydazę NADPH, powodujacc wzrost produkcji $\mathrm{H}_{2} \mathrm{O}_{2}$, który bezpośrednio zaangażowany jest $\mathrm{w}$ indukowanie powstawania korzeni bocznych przez modulowanie ekspresji genów regulatorowych cyklu komórkowego oraz regulację ścieżki sygnału auksynowego (MEI i współaut. 2017).

Proces starzenia organów roślinnych jest końcowym etapem ich rozwoju, podczas którego słabna funkcje życiowe. Na przykładzie ciętych kwiatów i owoców potwierdzono, że siarkowodór opóźnia otwieranie kwiatów, hamuje obumieranie i gnicie owoców. $\mathrm{H}_{2} \mathrm{~S}$ przeciwdziała stresowi oksydacyjnemu, obniżając zawartość reaktywnych form tlenu i poziom peroksydacji lipidów poprzez aktywacje enzymów antyoksydacyjnych w tych organach (ZHANG i współaut. 2011, NI i współaut. 2016). Ponadto stwierdzono, że siarkowodór opóźnia dojrzewanie owoców działajac jako antagonista etylenu. $\mathrm{H}_{2} \mathrm{~S}$ redukuje ekspresję genów kodujacych enzymy odpowiedzialne za biosyntezę etylenu i modyfikuje transkrypcję genów receptora etylenu, w efekcie prowadzacc do hamowania ścieżki sygnałowej etylenu (GE i współaut. 2017). Najnowsze badania wskazuja, że siarkowodór funkcjonuje jako istotny regulator indukowanego ciemnościa starzenia liści. Wykazano, że zapobiega on degradacji chlorofilu przez indukcję reakcji innych niż znane szlaki sygnałowe uruchamiane podczas starzenia, do których należy autofagia. Efekt wywołany przez $\mathrm{H}_{2} \mathrm{~S}$ zwiazany jest $z$ homeostaza NO. Siarkowodór moduluje ekspresję genów odpowiedzialnych za starzenie w sposób zależny od NO (WEI i współaut. 2017). Natomiast na przykładzie Arabidpsis stwierdzono, że $\mathrm{H}_{2} \mathrm{~S}$ pełni funkcję regulatorowa $\mathrm{w}$ procesie autofagii indukowanej niedoborem składników odżywczych, działając jako represor tego procesu. Nie poznano dotąd szczegółowo mechanizmu działania 
Stres abiotyczny:

zasolenie, metale ciężkie, wysoka temperatura, niska temperatura, niedostatek wody, niedobór tlenu

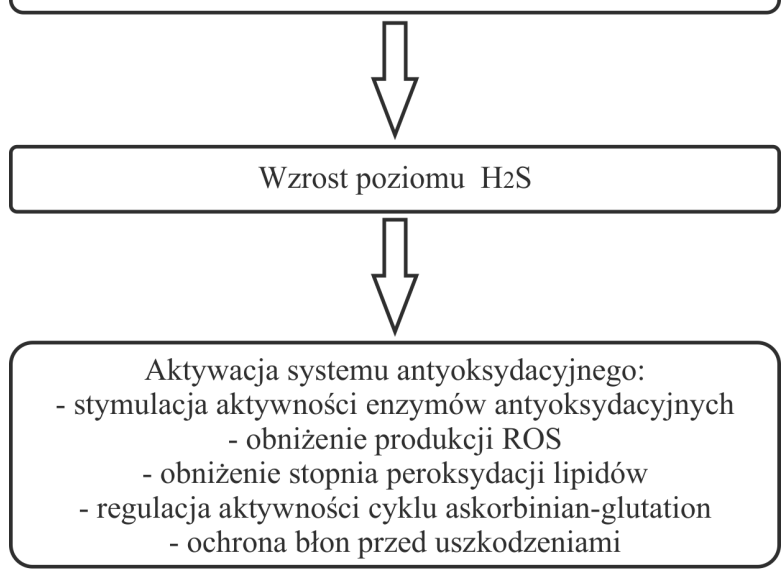

Regulacja poziomu toksycznych jonów (sodu, metali) w cytoplazmie:

- ograniczenie wnikania jonów do wnętrza komórek

- promowanie gromadzenia jonów wewnątrz wakuoli

Aktywacja biosyntezy cząsteczek osmoregulacyjnych (proliny, węglowodanów)

i zwiększenie względnej zawartości wody

Indukcja ekspresję specyficznych genów (białek HSP, czynników transkrypcyjnych, miRNA)

Ochrona aparatu fotosyntetycznego

Stymulacja kiełkowania i wzrostu roślin

Ryc. 2. Rola $\mathrm{H}_{2} \mathrm{~S}$ w procesach adaptacyjnych, uruchamianych $\mathrm{w}$ roślinach poddanych działaniu stresów abiotycznych.

siarkowodoru. Proponuje się jednak, że $\mathrm{H}_{2} \mathrm{~S}$ może odwracalnie, potranslacyjnie modyfikować białka uczestniczace w ubikwitynacji i tworzeniu autofagosomu (BATOKO i współaut. 2017).

\section{UDZIAE W ADAPTACJI ROŚLIN DO STRESÓW ABIOTYCZNYCH}

Endogenna produkcja siarkowodoru, podobnie jak innych wtórnych przekaźników, zwiększa się gwałtownie w roślinach pod wpływem różnych czynników stresowych. Wykazano, że zawartość $\mathrm{H}_{2} \mathrm{~S}$ rośnie nawet 2-2,5-krotnie w tkankach wielu gatunków roślin poddanych działaniu stresów abiotycznych. Uważa się zatem, że wzrost poziomu $\mathrm{H}_{2} \mathrm{~S}$ jest wspólnym elementem reakcji obronnych roślin, ściśle zwiazanym $z$ uruchamianiem procesów adaptacyjnych. Potwierdzono w licznych publikacjach, że zwiększona zawartość siarkowodoru, wynikajaca ze wzro- stu aktywności enzymów odpowiedzialnych za jego biosyntezę (głównie desulfhydrazy L-cysteiny), skorelowana jest ze wzmożona tolerancją na metale ciężkie, zasolenie, suszę, niska i wysoka temperaturę, promieniowanie UV czy niedobór tlenu (LI Z. G. i współaut. 2016, HE i współaut. 2018). Z drugiej strony natomiast, trwajace od dekady intensywne badania wskazują, że wcześniejsze podanie roślinom egzogennych donorów $\mathrm{H}_{2} \mathrm{~S}$ prowadzi do nabywania przez nie dodatkowej odporności na zmieniające się, niekorzystne warunki środowiskowe (Ryc. 2).

\section{STRES SOLNY}

Rośliny poddane działaniu wysokich stężeń $\mathrm{NaCl}$ wykazuja wyraźne uszkodzenia liści w postaci więdnięcia, zasychania i nekroz na brzegach blaszki liściowej. Podanie roślinom egzogennego siarkowodoru powoduje złagodzenie negatywnych efektów indukowanych przez zasolenie, umożliwia zachowanie turgoru w liściach i znacznie ogranicza pojawianie się zmian nekrotycznych (FOTOPOULOS i współaut. 2013). Siarkowodór poprawia przeżywalność roślin w zasolonym środowisku. Wpływa na wzrost intensywności fotosyntezy, przewodnictwa szparkowego, zawartości chlorofilu, karotenoidów i białka. Zwiększa akumulację proliny i rozpuszczalnych węglowodanów (DA-SiLVA i MoDOLO 2018).

Jednym $z$ pierwszych skutków działania wysokiego zasolenia, które pojawiaja się w komórkach roślinnych, jest stres oksydacyjny. Niekontrolowana nadprodukcja ROS prowadzi do peroksydacji lipidów, oksydacji białek i wypływu elektrolitów. Zaobserwowano, że podanie roślinom $\mathrm{H}_{2} \mathrm{~S}$ przed traktowaniem ich chlorkiem sodu stymuluje aktywność enzymów antyoksydacyjnych, w tym katalazy (CAT) i dysmutazy ponadtlenkowej (SOD), obniżajacc jednocześnie poziom $\mathrm{H}_{2} \mathrm{O}_{2}$. Zwiększa się aktywność enzymów zaangażowanych w biosyntezę glutationu (GSH) i kwasu askorbinowego (AsA), odpowiedzialnych za utrzymanie wysokiego stanu redoks tych zwiąków. Jednocześnie obserwuje się spadek aktywności lipoksygenazy i stopnia peroksydacji lipidów (FOTOPOULOS i współaut. 2013, DA-Silva i Modolo 2018).

Stres solny wiąże się $z$ napływem wysokich stężeń jonów $\mathrm{Na}^{+}$do wnętrza komórek $\mathrm{i}$ ich toksycznym wpływem na metabolizm komórkowy. Stwierdzono, że egzogenny $\mathrm{H}_{2} \mathrm{~S}$ powoduje wzrost współczynnika $\mathrm{K}^{+} / \mathrm{Na}^{+}$, co zwiazane jest ze wzrostem transportu jonów potasu w stosunku do jonów sodu przez nieselektywne kanały jonowe i plazmolemowy antyporter $\mathrm{Na}^{+} / \mathrm{H}^{+}$SOS1. Siarkowodór indukuje ekspresję genów antyportera SOS1, 
a także ekspresję i fosforylację plazmolemowej $\mathrm{H}^{+}$-ATPazy. $\mathrm{Z}$ drugiej strony natomiast potwierdzono, że $\mathrm{H}_{2} \mathrm{~S}$ uczestniczy w utrzymaniu homeostazy $\mathrm{K}^{+} / \mathrm{Na}^{+}$obniżajac ekspresję genów kodujących kanały odpowiedzialne za wypływ jonów potasu i zabezpieczajac w ten sposób komórki przed ich utratą. Utrzymanie niskiego poziomu $\mathrm{Na}^{+}$w cytoplazmie możliwe jest dzięki akumulacji toksycznych jonów wewnatrz wakuoli. Badania wykazały, że $\mathrm{H}_{2} \mathrm{~S}$ zwiększa transkrypcję genów wakuolarnej $\mathrm{H}^{+}$-ATPazy oraz wakuolarnego $\mathrm{Na}^{+}$/ $\mathrm{H}^{+}$antyportera, odpowiedzialnych za aktywny transport jonów sodu przez tonoplast do wnętrza wakuoli (LAI i współaut. 2014, CHEN i współaut. 2015, DENG i współaut. 2016, DA-Silva i Modolo 2018).

\section{STRES ZWIAZANY Z OBECNOŚCIA TOKSYCZNYCH METALI I METALOIDÓW}

Toksyczność metali negatywnie wpływa na wiele aspektów wzrostu i rozwoju roślin, powoduje hamowanie kiełkowania, zmiany morfologiczne, upośledzenie w dojrzewaniu owoców i procesie fotosyntezy. Dotychczasowe badania wskazuja, że siarkowodór może odgrywać istotna rolę w reakcjach obronnych roślin uruchamianych w odpowiedzi na arsen, bor, chrom, glin, miedź, kadm, ołów czy cynk (HE i współaut. 2018). Podobnie jak w przypadku stresu solnego, obecność w środowisku nadmiaru metali, zwłaszcza metali ciężkich, prowadzi do oksydacyjnych uszkodzeń w komórkach roślinnych, czego konsekwencja jest przerwanie płynności błon, zaburzenia metabolizmu, a także aktywacja programowanej śmierci. Podanie donorów $\mathrm{H}_{2} \mathrm{~S}$ obniża indukowana jonami metali produkcje ROS (nadtlenku wodoru i anionorodnika ponadtlenkowego), aktywuje enzymy antyoksydacyjne, zmniejsza poziom peroksydacji lipidów, a także reguluje aktywność cyklu askorbinian-glutation (AsA-GSH). Takie działanie siarkowodoru zaobserwowano w obecności wysokich stężeń kadmu, miedzi, glinu, ołowiu czy arsenu (Guo i współaut. 2016, Li Z. G. i współaut. 2016)

Rola $\mathrm{H}_{2} \mathrm{~S}$ nie ogranicza się do przeciwdziałania stresowi oksydacyjnemu. Traktowanie roślin siarkowodorem redukuje akumulację toksycznych jonów w cytoplazmie. W przypadku stresu wywołanego przez kadm zaobserwowano, że $\mathrm{H}_{2} \mathrm{~S}$ zapobiega wnikaniu jonów $\mathrm{Cd}^{2+}$ do wnętrza komórek za pośrednictwem kanałów wapniowych i promuje ich gromadzenie wewnątrz wakuoli, aktywując tonoplastowy $\mathrm{Cd}^{2+} / \mathrm{H}^{+}$antyporter. Analiza roślin poddanych działaniu chromu ujawniła, że $\mathrm{H}_{2} \mathrm{~S}$ wraz $\mathrm{z}$ jonami wapnia obniża akumulację jonów $\mathrm{Cr}^{2+}$, regulujac ekspresję genów kodujaccych transportery metali. Z jednej strony, hamowana jest transkrypcja genów transporterów odpowiedzialnych za pobieranie metalu, $z$ drugiej natomiast, obserwuje się wzrost ekspresji genów kodujących białka zaangażowane w usuwanie metalu $\mathrm{z}$ cytosolu. Podobnie, w roślinach traktowanych wysokimi stężeniami cynku stwierdzono, że $\mathrm{H}_{2} \mathrm{~S}$ obniża cytosolowy poziom jonów $\mathrm{Zn}^{2+} \mathrm{w}$ korzeniach poprzez hamowanie ekspresji genów kodujacych transportery odpowiedzialne za pobieranie i utrzymanie homeostazy $\mathrm{Zn} \mathrm{w}$ komórkach. Dodatkowo wykazano, że siarkowodór wzmaga transkrypcję i aktywność metalotionein i fitochelatyn, uczestniczacych w usuwaniu $z$ komórek nadmiaru szkodliwych jonów metali (SuN i współaut. 2013, GUO i współaut. 2016, LI Z. G. i współaut. 2016, LIU i współaut. 2016, HE i współaut. 2018).

Siarkowodór bierze udział w regulacji nie tylko białek transportujacych jony metali ciężkich, ale także innych transporterów, istotnych dla roślin. W przypadku stresu wywołanego przez glin dowiedziono, że podanie $\mathrm{H}_{2} \mathrm{~S}$ przywraca aktywność plazmolemowej $\mathrm{H}^{+}$-ATPazy, która hamowana jest przez jony $\mathrm{Al}^{3+}$. Ponadto, zaobserwowano indukowana przez $\mathrm{H}_{2} \mathrm{~S}$ nadekspresję genu kodujacego transporter cytrynianu i w konsekwencji zwiększona sekrecję cytrynianu, chelatora metali, przez korzenie (GUO i współaut. 2016, HE i współaut. 2018).

Jak już wcześniej wspomniano, jony metali, takie jak chrom, miedź i glin, hamuja kiełkowanie nasion, jednak efekt metali można cofnąć przez podanie siarkowodoru (Fotopoulos i współaut. 2013, Guo i współaut. 2016). Podobny korzystny wpływ $\mathrm{H}_{2} \mathrm{~S}$ na procesy wzrostowe odnotowano w przypadku roślin traktowanych borem. Nadmiar jonów boru wyraźnie hamuje wzrost korzeni, co spowodowane jest represja genów kodujacych białka kontrolujace proces powstawania ściany komórkowej, w tym ekspansyny i enzymy uczestniczace w przemianach pektyn. Potraktowanie siewek siarkowodorem przywraca wzrost korzeni, sugerujacc udział tej czasteczki w biosyntezie ściany komórkowej (WANG i współaut. 2010).

\section{STRES SUSZY}

Niedobór wody jest jednym $z$ najistotniejszych czynników środowiskowych, które decyduja o wzroście i rozwoju roślin, a także o ich produktywności, co ma ogromne znaczenie dla rolnictwa. Podobnie do innych czynników stresowych, deficyt wody prowadzi do stresu oksydacyjnego w komórkach. Potwierdzono, że potraktowanie siarkowodorem obniża indukowany susza poziom peroksydacji 
lipidów, stężenie $\mathrm{H}_{2} \mathrm{O}_{2}$ i wypływ elektrolitów, zwiększa aktywność enzymów antyoksydacyjnych oraz zawartość zredukowanego glutationu $\mathrm{i}$ askorbinianu (LI 2013). $\mathrm{H}_{2} \mathrm{~S}$ indukuje ekspresje specyficznych genów uruchamianych w odpowiedzi na susze (m.in. czynników transkrypcyjnych $\mathrm{z}$ rodziny DREB/ $\mathrm{CBF}$ ), podnosi przeżywalność roślin, zwiększa biomasę pędów i korzeni, a także chroni przed degradacja chlorofilu. Wpływa na zmniejszenie rozmiarów szparek, zwiększając względna zawartość wody, co zwiąane jest $z$ aktywacja genów kodujących receptor kwasu abscysynowego i indukcja ścieżki sygnałowej z udziałem ABA. Dzięki temu siarkowodór umożliwia roślinom normalny wzrost $\mathrm{w}$ warunkach ograniczonej dostępności wody w środowisku (FOTOPOULOS i współaut. 2013, BANERJEE i współaut. 2018). Badania ostatnich lat sugeruja, że ważnym czynnikiem modulującym reakcję roślin na stres suszy jest micro RNA (miRNA). Wykazano, że $\mathrm{H}_{2} \mathrm{~S}$ uczestniczy $\mathrm{w}$ regulacji ekspresji czasteczek miRNA pojawiajacych się specyficznie $\mathrm{w}$ odpowiedzi na deficyt wody w komórkach, może zatem wpływać na ekspresję docelowych genów warunkujących przetrwanie okresów suszy (SHEN i współaut. 2013).

\section{STRES WYWOŁANY WYSOKA TEMPERATURA}

Liczne badania podkreślaja, że wysoka temperatura powoduje denaturację białek i ich agregację, wzrost płynności błon i zaburzenia $\mathrm{w}$ ich stabilności. Konsekwencja tych zmian jest inaktywacja enzymów, wstrzymanie syntezy białek i trwałe uszkodzenia komórek prowadzace nawet do ich śmierci (FOTOPOULOS i współaut. 2013, GuO i współaut. 2016). Siarkowodór łagodzi skutki stresu cieplnego zwiększając fluorescencję chlorofilu, przewodnictwo szparkowe i zawartość wody $\mathrm{w}$ roślinach, a także obniżając stopień peroksydacji lipidów. Podanie $\mathrm{H}_{2} \mathrm{~S}$ nie tylko podwyższa aktywność enzymów antyoksydacyjnych i poziom zredukowanego glutationu i askorbinianu $\mathrm{w}$ stresowanych roślinach, ale także zwiększa ekspresję genów kodujących białka szoku cieplnego (ang. heat shock proteins, HSP) i plazmolemowe akwaporyny (ang. plasma membrane intrinsic protein, PIP (CHRISTOU i współaut. 2014, BANERJEE i współaut. 2018). Wykazano, że wzrost tolerancji na wysoka temperaturę, indukowany przez $\mathrm{H}_{2} \mathrm{~S}$, zwiąany jest $\mathrm{z}$ transdukcja sygnału wapniowego $i$ akumulacja endogennej proliny. Traktowanie siarkowodorem podnosi aktywność syntetazy uczestniczacej w biosyntezie proliny i jednocześnie hamuje aktywność dehydrogenazy odpowiedzialnej za jej przemiany kataboliczne. Oprócz proliny, zwiększa się zawartość innych substancji osmoregulacyjnych, jak betaina i trechaloza (LI i współaut. 2013, BANERJEE i współaut. 2018).

\section{STRES WYWOŁANY NISKA TEMPERATURA}

Podobnie jak wysoka temperatura, także niskie temperatury wywołuja uszkodzenia w komórkach roślinnych. Warunki stresowe dla roślin pojawiaja się zarówno przy $0-10^{\circ} \mathrm{C}$ (stres chłodu), jak i poniżej $0^{\circ} \mathrm{C}$ (stres wywolany przez zamarzanie), prowadzac do stresu oksydacyjnego i osmotycznego (Li Z. G. i współaut. 2016, BANERJEE i współaut. 2018). Rola siarkowodoru polega na przeciwdziałaniu niekorzystnym skutkom niskich temperatur, w tym uszkodzeniom oksydacyjnym, analogicznie jak $\mathrm{w}$ przypadku działania innych srodowiskowych czynników stresowych. Potwierdzono, że podanie $\mathrm{H}_{2} \mathrm{~S}$ moduluje poziom antyoksydantów, aktywność enzymów antyoksydacyjnych, zawartość reaktywnych form tlenu $\mathrm{i}$ azotu, peroksydację lipidów i przepuszczalność błon, zwiększając przeżywalność roślin. Podobnie jak zaobserwowano w warunkach wysokiej temperatury, jednym $z$ efektów działania $\mathrm{H}_{2} \mathrm{~S}$ jest wzrost akumulacji proliny. Zwiększa się także zawartość innych osmoregulatorów, w tym rozpuszczalnych cukrów, i poziom fenoli w komórkach (LUO i współaut. 2015, Li Z. G. i współaut. 2016, BANERJEe i współaut. 2018). Na przykładzie owoców poddanych działaniu niskiej temperatury wykazano, że siarkowodór stymuluje aktywności ATPaz $\left(\mathrm{H}^{+}\right.$-ATPazy i $\mathrm{Ca}^{2+}$ -ATPazy), oksydazy cytochromu c i dehydrogenazy bursztynianowej, utrzymując wysoki poziom ATP $\mathrm{w}$ komórkach i ich status energetyczny (LI D. i współaut. 2016a).

\section{STRES SPOWODOWANY NIEDOBOREM TLENU}

Deficyt tlenu w tkankach roślinnych (hipoksja), w stosunku do aktualnego zapotrzebowania, jest czynnikiem stresogennym, prowadzacym do niedotlenienia i zaburzeń w wytwarzaniu energii. $Z$ sytuacja taka mamy do czynienia, kiedy rośliny okresowo lub stale zalewane sa woda (BANERJEE i współaut. 2018). W nielicznych dotad badaniach potwierdzano, że podanie siarkowodoru łagodzi negatywne skutki hipoksji. Zapobiega pojawianiu się zmian nekrotycznych i chroni błony komórkowe przed oksydacyjnymi uszkodzeniami. Dodatkowo wykazano, że korzystny wpływ $\mathrm{H}_{2} \mathrm{~S}$ zwiazany jest $z$ hamowaniem biosyntezy etylenu (LI $Z$. G. i współaut. 2016). 


\section{INTERAKCJE H S Z INNYMI CZASTECZKAMI SYGMAEOWYMI}

Dotychczasowe prace wskazują, że $\mathrm{H}_{2} \mathrm{~S}$ wchodzi w interakcje $z$ innymi cząsteczkami sygnałowymi, do których należa $\mathrm{NO}, \mathrm{H}_{2} \mathrm{O}_{2}$ i $\mathrm{CO}$, oraz hormony roślinne, głównie IAA, ABA i etylen, a według nielicznych dotad badań także kwas jasmonowy i salicylowy. Dzięki tym interakcjom tworzy się złożona sieć ścieżek sygnałowych, zaangażowanych w kontrolowanie podstawowych procesów fizjologicznych roślin. Jednak jak dotąd nie poznano szczegółowo mechanizmu oddziaływania $\mathrm{H}_{2} \mathrm{~S} z$ innymi molekułami (JIN i PEI 2015, GUO i współaut. 2016, BANERJEE i współaut. 2018). Najwięcej informacji, dostępnych w literaturze, dotyczy wzajemnych zależności pomiędzy $\mathrm{H}_{2} \mathrm{~S}$ a $\mathrm{NO} \mathrm{i}_{2} \mathrm{O}_{2}$.

Wiele cech, które wykazuje siarkowodór, przypomina funkcjonalna i biologiczna aktywność tlenku azotu. Badania przeprowadzone na komórkach zwierzęcych potwierdziły, że endogennie generowane $\mathrm{NO}$ i $\mathrm{H}_{2} \mathrm{~S}$ moga oddziaływać ze soba, a interakcje pomiędzy obu cząsteczkami odgrywaja istotna fizjologiczna rolę $\mathrm{w}$ regulacji pracy serca, funkcjonowaniu układu krażenia i procesach zapalnych. Warto jednak podkreślić, że jedne eksperymenty wykazały, że $\mathrm{NO}$ i $\mathrm{H}_{2} \mathrm{~S}$ moga pobudzać nawzajem swoja produkcję, inne natomiast ujawnily odwrotny efekt (PAE i współaut. 2009, KolluRU i współaut. 2013). Wzajemne zależności pomiędzy działaniem $\mathrm{NO}$ i $_{2} \mathrm{~S}$ wykazano także u roślin. Obie czasteczki sa zaangażowane w regulację ruchów aparatów szparkowych. Jak już wcześniej wspomniano, $\mathrm{H}_{2} \mathrm{~S}$ obniża akumulację NO w komórkach szparkowych podczas otwierania szparek. Z drugiej strony istnieja dowody na to, że tlenek azotu może działać jako nadrzędny element w stosunku do siarkowodoru podczas zamykania szparek (GARCíA-MATA i LAMATtina 2013). Podobne dane uzyskano badajac proces powstawania korzeni przybyszowych. Sugeruja one, że NO jest istotnym czynnikiem zaangażowanym w zależna od $\mathrm{H}_{2} \mathrm{~S}$ indukcję tego procesu (ZHANG i współaut. 2009). Rola siarkowodoru w adaptacji roślin do stresów abiotycznych wiąże się często $\mathrm{z}$ akumulacja tlenku azotu w tkankach. Potwierdzono, że NO bierze udział $\mathrm{w}$ indukowanym przez $\mathrm{H}_{2} \mathrm{~S}$ wzroście tolerancji na zasolenie i obecność metali ciężkich sugerując, że NO uczestniczy w ścieżce sygnałowej zależnej od $\mathrm{H}_{2} \mathrm{~S}$, a interakcja pomiędzy obiema cząsteczkami może odbywać się poprzez S-nitozylację i S-sulfhydracje białek zaangażowanych w ich biosyntezę (GuO i współaut. 2016, HE i współaut. 2018). W przeciwieństwie do powyższych danych istnieja doniesienia potwierdzajace, że traktowanie roślin donorami siarkowodoru obniża pozom NO w tkankach roślin poddanych działaniu stresu solnego (DA-SILVA i Modolo 2018). Inne wyniki wskazuja natomiast, że ścieżka sygnałowa indukowana przez NO w roślinach traktowanych kadmem blokowana jest przez inhibitory i zmiatacze $\mathrm{H}_{2} \mathrm{~S}$, zatem siarkowodór również może być ważnym elementem aktywowanym przez NO, uczestniczacym w reakcjach obronnych roślin (JIN i PEI 2015).

Liczne dane wskazuja, że $\mathrm{H}_{2} \mathrm{~S}$ odgrywa ważna rolę $\mathrm{w}$ transdukcji sygnału $\mathrm{z}$ udziałem $\mathrm{H}_{2} \mathrm{O}_{2}$. Jednak interakcje pomiędzy tymi dwoma wtórnymi przekaźnikami w regulacji procesów fizjologicznych różnia się w zależności od gatunku czy warunków środowiskowych. Zaobserwowano, że obie czasteczki moga stymulować proces kiełkowania nasion. $Z$ jednej strony wykazano, że siarkowodór uczestniczy $\mathrm{w}$ ścieżce sygnałowej indukowanej przez $\mathrm{H}_{2} \mathrm{O}_{2}$, promujacej proces kiełkowania. Traktowanie nasion nadtlenkiem wodoru zwiększa aktywność desulfhydrazy L-cysteiny i akumulacje $\mathrm{H}_{2} \mathrm{~S}$ (LI i współaut. 2012). $Z$ drugiej strony natomiast stwierdzono, że to $\mathrm{H}_{2} \mathrm{~S}$ może pełnić nadrzędna rolę $\mathrm{w}$ stosunku do $\mathrm{H}_{2} \mathrm{O}_{2}$ w tym procesie ( $\mathrm{LI} \mathrm{i} \mathrm{HE}$ 2015). Badania potwierdzaja, że stresy abiotyczne indukuja biosyntezę zarówno $\mathrm{H}_{2} \mathrm{~S}$, jak i $\mathrm{H}_{2} \mathrm{O}_{2}$ w tkankach roślin. Co więcej, siarkowodôr zdolny jest wzmacniać korzystny wplyw nadtlenku wodoru na wzrost tolerancji roślin na czynniki stresowe. Wykazano, że $\mathrm{H}_{2} \mathrm{~S}$ uczestniczy $\mathrm{w}$ indukowanych przez $\mathrm{H}_{2} \mathrm{O}_{2}$ mechanizmach umożliwiających adaptację do wysokich temperatur, zwiększając przeżywalność siewek (LI i współaut. 2015). W przeciwieństwie do powyższych wyników, na przykładzie roślin poddanych działaniu kadmu zaobserwowano, że traktowanie donorem siarkowodoru obniża endogenny poziom $\mathrm{H}_{2} \mathrm{O}_{2} \mathrm{w}$ tkankach (MOSTOFA i współaut. 2015, ZHANG i współaut. 2015), sugerujac, że $\mathrm{H}_{2} \mathrm{~S}$ przeciwdziała generowaniu reaktywnych from tlenu i uszkodzeniom oksydacyjnym, które pojawiaja się jako negatywne skutki działania czynników stresowych. Przeciwstawny efekt siarkowodoru i nadtlenku wodoru na funkcjonowanie białek uczestniczacych $\mathrm{w}$ procesach adaptacyjnych potwierdzono na przykładzie wakuolarnej $\mathrm{H}^{+-}$ -ATPazy, której aktywność jest stymulowana przez $\mathrm{H}_{2} \mathrm{~S}$ i hamowana przez $\mathrm{H}_{2} \mathrm{O}_{2}$ (KABAEA $\mathrm{i}$ współaut. 2019).

\section{PODSUMOWANIE}

Intensywne badania, które przeprowadzono na przestrzeni ostatniej dekady wykazały, że w roślinach funkcjonuje wiele dróg percepcji $\mathrm{H}_{2} \mathrm{~S}$ i transdukcji sygnału $z$ jego 
udziałem. Wciaż identyfikowane sa nowe elementy ścieżek sygnałowych aktywowanych przez $\mathrm{H}_{2} \mathrm{~S}$, wśród nich kinazy białkowe i czynniki transkrypcyjne. Udowodniono, że kinaza zależna od wapnia i kalmoduliny (ang. calcium-dependent protein kinase, CDPK) odpowiedzialna jest za fosforylację i stymulację aktywności desulfhydraz oraz wzrost poziomu siarkowodoru w roślinach poddanych działaniu kadmu (QIAO i współaut. 2016). Natomiast kinaza MPK4, z rodziny MAPK (ang. mitogen-activated protein kinases), jest ważnym elementem indukowanej przez $\mathrm{H}_{2} \mathrm{~S}$ odporności roślin na działanie niskich temperatur (DU i współaut. 2017). Najnowsze dane sugeruja, że czynniki transkrypcyjne $z$ rodziny WRKY moga funkcjonować jako cząsteczki regulatorowe, modulujące ekspresję genów kodujących enzymy odpowiedzialne za biosyntezę $\mathrm{H}_{2} \mathrm{~S}$ w roślinach uprawianych na pożywkach $\mathrm{z}$ dodatkiem metali ciężkich (LIU i współaut. 2015). Na przykładzie roślin traktowanych chromem potwierdzono, że jony wapnia i kalmodulina wchodza $\mathrm{w}$ interakcję $\mathrm{z}$ czynnikiem transkrypcyjnym typu bZIP, TGA3, wzmagajac jego wiazanie do promotora genu $L C D$, kodujacego desulfhydrazę L-cysteiny, i w konsekwencji zwiększajac produkcję $\mathrm{H}_{2} \mathrm{~S}$ w tkankach (FANG i współaut. 2017).

Pomimo że istnieje wiele dowodów świadczacych o ważnej roli siarkowodoru jako cząsteczki sygnałowej, uczestniczącej w regulacji procesów fizjologicznych i w reakcjach obronnych roślin, wciąż różne kwestie pozostaja nierozstrzygnięte. Jednym $z$ takich zagadnień jest sprawa receptora (czy białek docelowych) dla $\mathrm{H}_{2} \mathrm{~S} . \mathrm{H}_{2} \mathrm{~S}$ łatwo dyfunduje przez błony i istnieje możliwość, że komórki roślinne nie posiadaja specyficznych receptorów (LI Z. G. i współaut. 2016). Jednak odkrycie, że siarkowodór może modulować aktywność białek poprzez proces odwracalnej S-sulfhydracji, nasuwa przypuszczenie, że modyfikowane białka moga funkcjonować jako sensory reagujace na zmiany $\mathrm{w}$ poziomie $\mathrm{H}_{2} \mathrm{~S}$ w komórkach. Taki punkt widzenia jednak wymaga dalszych badań.

$$
\text { Streszczenie }
$$

Przez długi czas siarkowodór uznawany był wyłacznie za silną toksynę, negatywnie oddziałujaca na organizmy żywe. Badania ostatnich lat wykazały korzystny wpływ $\mathrm{H}_{2} \mathrm{~S}$, podawanego $\mathrm{w}$ niskich stężeniach, na funkcjonowanie zarówno zwierzat jak i roślin. Potwierdziły także, że siarkowodór jest czasteczka sygnałowa, podobnej do dwóch znanych gazowych transmiterów, tlenku azotu i tlenku węgla. W komórkach roślinnych zidentyfikowano enzymy odpowiedzialne za generowanie $\mathrm{H}_{2} \mathrm{~S}$. Należą do nich głównie zlokalizowane w cytosolu desulfhydrazy, a także obecna $\mathrm{w}$ chloroplastach reduktaza siarczynowa oraz mitochondrialna syntaza $\beta$-cyjanoalaniny. Liczne badania wykazały, że poziom $\mathrm{H}_{2} \mathrm{~S}$ zwiększa się wyraźnie w tkankach roślin w odpowiedzi na działanie niekorzystnych czynników środowiskowych, takich jak zasolenie, metale ciężkie, niedostatek wody czy wysokie i niskie temperatury, sugerujac, że pełni on istotna funkcję w adaptacji roślin do stresów abiotycznych. Uważa się, że głównym mechanizmem działania $\mathrm{H}_{2} \mathrm{~S}$ jest S-sulfhydracja, czyli potranslacyjna modyfikacja reaktywnych reszt cysteiny w białkach.

\section{LITERATURA}

Álvarez C., Calo L., Romero L. C., García I., GOTOR C., 2010. An O-acetylserine(thiol)lyase homolog with L-cysteine desufhydrase activity regulates cysteine homeostasis in Arabidopsis. Plant Physiol. 152, 656-669.

Aroca A., SERna A., Gotor C., Romero L. C., 2015. S-sulfhydration: a cysteine posttranslational modification in plant systems. Plant Physiol. 168, 334-342.

ARocA A., BENITO J. M., Gotor C., ROMERo L. C., 2017. Persulfidation proteome reveals the regulation of protein function by hydrogen sulfide in diverse biological processes in Arabidopsis. J. Exp. Bot. 68, 4915-4927.

BANERJEE A., TRIPATHIB D. K., RoychoudhuRY A., 2018. Hydrogen sulphide trapeze: Environmental stress amelioration and phytohormone crosstalk. Plant Physiol. Biochem. 132, 46-53.

Batoko H., Dagdas Y., BAlUsKa F., SiRKO A., 2017. Understanding and exploiting autophagy signalling in plants. Ess. Biochem. 61, 675685 .

BURANDT P., SCHMIDT A., PAPENBROCK J., 2002. Three O-acetyl-L-serine(thiol)lyase isoenzymes from Arabidopsis catalyse cysteine synthesis and cysteine desulfuration at different $\mathrm{pH}$ values. J. Plant Physiol. 159, 111-119.

Chen J., Wu F. H., WANG W. H., ZHeng C. J., LIN G. H., DONG X. J., HE J. X., PEI Z. M., ZHENG H. L., 2011. Hydrogen sulphide enhances photosynthesis through promoting chloroplast biogenesis, photosynthetic enzyme expression, and thiol redox modification in Spinacia oleracea seedlings. J. Exp. Bot. 62, 4481-4493.

Chen J., Wang W. H., Wu F. H., He E. M., LiU X., SHANGGUAN Z. P., ZHENG H. L., 2015. Hydrogen sulfide enhances salt tolerance through nitric oxide-mediated maintenance of ion homeostasis in barley seedling roots. Sci. Rep. $5,1-19$.

Christou A., Filippou P., Manganaris G. A., FoTOPOUlOS V., 2014. Sodium hydrosulfide induces systemic thermotolerance to strawberry plants through transcriptional regulation of heat shock proteins and aquaporin. BMC Plant Biol. 14, 42.

Cuevasanta E., Lange M., Bonanata J., Coitiño E. L., FERRer-Sueta G., Filipovic M. R., ALVAREZ B., 2015. Reaction of hydrogen sulfide with disulfide and sulfenic acid to form the strongly nucleophilic persulfide. J. Biol. Chem. 290, 26866-26880.

DA-Silva C. J., Modolo L. V., 2018. Hydrogen sulfide: a new endogenous player in an old mechanism of plant tolerance to high salinity. Acta Bot. Brasil. 32, 150-160.

Deng Y. Q., BaO J., Yuan F., Liang X., Feng Z. T., WANG B. S., 2016. Exogenous hydrogen sulfide alleviates salt stress in wheat seed lings by decreasing $\mathrm{Na}^{+}$content. Plant Growth Regul. 79, 391-399.

DOOLEY F. D., NAIR S. P., WARD P. D., 2013. Increased growth and germination success in 
plants following hydrogen sulfide administration. PLoS One 8, e62048.

DU X., JiN Z., LIU D., YANG G., PEI Y., 2017. Hydrogen sulfide alleviates the cold stress through MPK4 in Arabidopsis thaliana. Plant Physiol. Biochem. 120, 112-119.

DUAN B., MA Y., JiANG M., YANG F., Ni L., LU W., 2015. Improvement of photosynthesis in rice (Oryza sativa L.) as a result of an increase in stomatal aperture and density by exogenous hydrogen sulfide treatment. Plant Growth Regul. 75, 33-44.

FANG H., LIU Z., LONG Y., LIANG Y., JIN Z., ZHANG L., LIU D., Li H., ZHAI J., PEI Y., 2017. The $\mathrm{Ca}^{2+} /$ calmodulin2-binding transcription factor TGA3 elevates LCD expression and $H_{2} S$ production to bolster $\mathrm{Cr}^{6+}$ tolerance in Arabidopsis. Plant J. 91, 1038-1050.

Fang T., CaO Z., LI J., Shen W., Huang L., 2014. Auxin-induced hydrogen sulfide generation is involved in lateral root formation in tomato. Plant Physiol. Biochem. 76, 44-51.

FILIPOVIC M. R., JovANOVIĆ V. M., 2017. More than just an intermediate: hydrogen sulfide signalling in plants. J. Exp. Bot. 68, 47334736.

Fotopoulos V., Christou A., MANGanaris G., 2013. Hydrogen sulfide as a potent regulator of plant responses to abiotic stress factors. [W]: Molecular approaches in plant abiotic stress. GAUR R. K., SHARMA P. (red). CRC Press, 353-373.

GARCÍA-MATA C., LAMATtina L., 2013. Gasotransmitters are emerging as new guard cell signaling molecules and regulators of leaf gas exchange. Plant Sci. 201-202, 66-73.

Ge Y., Hu K. D., Wang S. S., Hu L. Y., Chen X. Y., LI Y. H., YANG Y., YANG F., ZHANG H., 2017. Hydrogen sulfide alleviates postharvest ripening and senescence of banana by antagonizing the effect of ethylene. PLoS One 12, e0180113.

Guo H., XiaO T., Zhou H., Xie Y., Shen W., 2016. Hydrogen sulfide: a versatile regulator of environmental stress in plants. Acta Physiol. Plant. 38, 16.

HANCOCK J. T., LISJAK M., TEKLIC T., WILSON I. D., Whiteman M., 2011. Hydrogen sulfide and signaling in plants. CAB Rev. 6, 1-7.

$\mathrm{HE}$ H., LI Y., HE L. F., 2018. The central role of hydrogen sulfide in plant responses to toxic metal stress. Ecotoxicol. Environ. Saf. 157, 403-408.

JiA H., HU Y., FAN T., Li J., 2015. Hydrogen sulfide modulates actin-dependent auxin transport via regulating $A B P$ s results in changing of root development in Arabidopsis. Sci. Rep. 5, 8251.

JIN Z., PEI Y., 2015. Physiological implications of hydrogen sulfide in plants: pleasant exploration behind its unpleasant odour. Oxid. Med. Cell. Longev. 2015, 397502.

JIN Z., PEI Y., 2016. Hydrogen sulfide: the shutter button of stomata in plants. Sci. China Life Sci. 59, 1187-1188.

KABAŁA K., ZBOIŃSKA M., GŁoWIAK D., RedA M., JAKUBOWSKA D., JANICKA M., 2019. Interaction between the signaling molecules hydrogen sulfide and hydrogen peroxide and their role in vacuolar $H^{+}$-ATPase regulation in cadmium-stressed cucumber roots. Physiol. Plant. 166, 688-704.

KABIL O., BANERJEE R., 2010. Redox biochemistry of hydrogen sulfide. J. Biol. Chem. 285, 21903-21907.
KIMURA H., 2012. Metabolic turnover of hydrogen sulfide. Front. Physiol. 3, 101.

Kolluru G. K., Shen X., BIR S. C., Kevil C. G., 2013. Hydrogen sulfide chemical biology: Pathophysiological roles and detection. Nitric Oxide 35, 5-20.

LaI D., MaO Y., Zhou H., LI F., Wu M., ZHANG J., HE Z., CUI W., XIE Y., 2014. Endogenous hydrogen sulfide enhances salt tolerance by coupling the reestablishment of redox homeostasis and preventing salt-induced $K^{+}$loss in seedlings of Medicago sativa. Plant Sci. 22, 117-129.

Li D., LimWachiranon J., Li L., Du R., LuO Z., 2016. Involvement of energy metabolism to chilling tolerance induced by hydrogen sulfide in cold-stored banana fruit. Food Chem. 208, 272-278.

Li L., Rose P., Moore P. K., 2011. Hydrogen sulfide and cell signaling. Annu. Rev. Pharmacol. Toxicol. 51, 169-187.

Li Z. G., 2013. Hydrogen sulfide: a multifunctional gaseous molecule in plants. Russ. J. Plant. Physiol. 60, 733-740.

LI Z. G., $\mathrm{HE}$ Q. Q., 2015. Hydrogen peroxide might be a downstream signal molecule of hydrogen sulfide in seed germination of mung bean (Vigna radiata). Biologia 70, 753-759.

Li Z. G., GONG M., LIU P., 2012. Hydrogen sulfide is a mediator in $\mathrm{H}_{2} \mathrm{O}_{2}$-induced seed germination in Jatropha curcas. Acta Physiol. Plant. 34, 2207-2213.

Li Z. G., DinG X. J., DU P. F., 2013. Hydrogen sulphide donor sodium hydrosulfide-improved heat tolerance in maize and involvement of proline. J. Plant Physiol. 170, 741-747.

Li Z. G., Luo L. J., Sun Y. F., 2015. Signal crosstalk between nitric oxide and hydrogen sulfide may be involved in hydrogen peroxide-induced thermotolerance in maize seedlings. Russ. J. Plant Physiol. 62, 507-514.

Li Z. G., MiN X., ZHOU Z. H., 2016. Hydrogen sulfide: a signal molecule in plant cross-adaptation. Front. Plant Sci. 7, 1621.

LisJAK M., TEKLIC T., Wilson I. D., Whiteman M., HANCOCK J. T., 2013. Hydrogen sulfide: environmental factor or signalling molecule? Plant Cell Environ. 36, 1607-1616.

Liu X., Chen J., Wang G. H., Wang W. H., Shen Z. J., LuO M. R., GaO G. F., Simon M., GHOTO K., ZHENG H. F., 2016. Hydrogen sulphide alleviates zinc toxicity by reducing zinc uptake and regulating genes expression of antioxidative enzymes and metallothioneins in roots of the cadmium/zinc hyperaccumulator Solanum nigrum L. Plant Soil 400, 177-192.

LIU Z. Q., FANG H. H., PEI Y. X., Jin Z. P., ZHANG L. P., LIU D. M., 2015. WRKY transcription factors down-regulate the expression of $H_{2} S$ generating genes, LCD and DES in Arabidopsis thaliana. Sci. Bull. 60, 995-1001.

Luo Z., LI D., Du R., Mou W., 2015. Hydrogen sulphide alleviates chilling injury of banana fruit by enhanced antioxidant system and proline content. Sci. Hortic. 183, 144-151.

MOSTOFA M. G., RAHMAN A., ANSARY M. M. U., WATANABE A., FUJiTA M., TRAN L. S. P., 2015. Hydrogen sulfide modulates cadmium-induced physiological and biochemical responses to alleviate cadmium toxicity in rice. Sci. Rep. 5, 14078.

Mei Y., Chen H., Shen W., Shen W., HuAng L., 2017. Hydrogen peroxide is involved in hydrogen sulfide-induced lateral root formation in tomato seedlings. BMC Plant Biol. 17, 162. 
MÓdis K., JU Y., AHMAD A., UNTEREINER A. A., ALTAANY Z., WU L., SZABO C., WANG R., 2016. S-sulfhydration of ATP synthase by hydrogen sulfide stimulates mitochondrial bioenergetics. Pharmacol. Res. 113, 116-124.

Mustafa A. K., Gadalla M. M., SEN N., Kim S., Mu W., GazI S. K., BARROW R. K., YANG G., WANG R., SNYDER S. H., 2009. $\mathrm{H}_{2} \mathrm{~S}$ signals through protein S-sulfhydration. Sci. Signal. 2: ra72.

Ni Z. J., Hu K. D., Song C. B., MA R. H., Li Z. R., ZHENG J. L., FU L. H., WeI Z. J., ZHANG H., 2016. Hydrogen sulfide alleviates postharvest senescence of grape by modulating the antioxidant defenses. Oxid. Med. Cell. Longev. 2016, 4715651.

PaE H. O., LeE Y. C., Jo E. K., Chung H. T. 2009. Subtle interplay of endogenous bioactive gases (NO, CO and $\mathrm{H}_{2} S$ ) in inflammation. Arch. Pharm. Res. 32, 1155-1162.

PAPENBROCK J., RIEMENSCHNEIDER A., KAMP A., Schulz-VogT H. N., SchmidT A., 2007. Char acterization of cysteine-degrading and $\mathrm{H}_{2} \mathrm{~S}-\mathrm{re}$ leasing enzymes of higher plant - from the field to the test tube and back. Plant Biol. 9, $582-588$.

QIAO Z. J., JING T., JiN Z., PEI Y., 2016. CDPKs enhance $\mathrm{Cd}$ tolerance through intensifying $H S$ signal in Arabidopsis thaliana. Plant Soil 398, 99-110.

RiEMENSCHNEIDER A., WEgele R., SCHMidT A., PAPENBROCK J., 2005. Isolation and characterization of a D-cysteine desulfhydrase protein from Arabidopsis thaliana. FEBS J. 272, 1291-1304.

Romero L. C., Aroca M. A., Laureano-Marín A. M., Moreno I., GARCía I., GotoR C., 2014. Cysteine and cysteine-related signaling pathways in Arabidopsis thaliana. Mol. Plant 7, 264-276.

ScHMIDT A., 2005. Metabolic background of $\mathrm{H}_{2} \mathrm{~S}$ release from plants. [W]: Proceedings of the 1st sino-german workshop on aspects of sulfur nutrition of plants. De Kok L. J., Schnug E. (red.). Landbauforschung Völkenrode 283, 121-129.

SHen J., Xing T., YuAN H., LiU Z., Jin Z., ZHANG L., PEI Y., 2013. Hydrogen sulphide improves drought tolerance in Arabidopsis thaliana by microRNA expressions. PloS One 8, e77047.

SUN J., WANG R., ZHANG X., YU Y., ZHAO R., LI Z., CHEN S., 2013. Hydrogen sulphide alle- viates cadmium toxicity through regulations of cadmium transport across the plasma and vacuolar membranes in Populus euphratica cells. Plant Physiol. Biochem. 65, 67-74.

TADEUSIEWICZ J., OlaS B., 2014. Siarkowodór gaz nie tylko o właściwościach toksycznych. Kosmos 63, 125-135.

WANG B. L., Shi L., Li Y. X., Zhang W. H., 2010. Boron toxicity is alleviated by hydrogen sul fide in cucumber (Cucumis sativus L.) seedlings. Planta 231, 1301-1309.

WANG R., 2002. Two's company, three's crowd: can $\mathrm{H}_{2} \mathrm{~S}$ be the third endogenous gaseous transmitter? FASEB J. 16, 1792-1798.

WANG R., 2012. Physiological implications of hydrogen sulfide: a whiff exploration that blossomed. Physiol. Rev. 92, 791-896.

WEDMANN R., ONDERKA C., WEI S., SZIJÁRTó I. A., MilJKovic J. L., Mitrovic A., Lange M., SAVITSKY S., YADAV P. K., TORREGROSSA R., HARRER E. G., HARRER T., ISHI I., GOLlASCH M., WoOd M. E., Galardon E., XIAN M., WHITEMAN M., BANERJEE R., FILIPOVIC M. R., 2016. Improved tag-switch method reveals that thioredoxin acts as depersulfidase and controls the intracellular levels of protein persulfidation. Chem. Sci. 7, 3414-3426.

WEI B., ZHANG W., CHAO J., ZHANG T., ZHAO T. NOCTOR G., LIU Y., HAN Y., 2017. Functional analysis of the role of hydrogen sulfide in the regulation of dark-induced leaf senescence in Arabidopsis. Sci. Rep. 7, 2615.

YANG G., 2014. Protein S-sulfhydration as a major sources of $\mathrm{H}_{2} \mathrm{~S}$ bioactivity. Rec. Clin. Invest. 1 , e337.

Zhang H., TANG J., LiU X. P., Wang Y., YU W., PENG W. Y., FANG F., MA D. F., Wei Z. J., HU L. Y., 2009. Hydrogen sulfide promotes root organogenesis in Ipomoea batatas, Salix matsudana and Glycine max. J. Integr. Plant Biol. 51, 1086-1094.

ZHANG H., Hu S. L., ZHANG Z. J., Hu L. Y., JiANG C. X., Wei Z. J., LIU J., WANG H. L., JiANG S. T., 2011. Hydrogen sulfide acts as a regulator of flower senescence in plants. Postharvest Biol. Tec. 60, 251-257.

ZhaNG L., PEI Y., WANG H., JiN Z., LIU Z., QIAO Z., FANG H., ZHANG Y., 2015. Hydrogen sulfide alleviates cadmium-induced cell death through restraining ROS accumulation in roots of Brassica rapa L. ssp. pekinensis. Oxid. Med. Cell. Longev. 2015, 804603. 
KOSMOS Vol. 68, 3, 451-463, 2019

Katarzyna KabaŁa, Justyna ŻEbrowska, Dorota Garbera

Department of Plant Molecular Physiology, Institute of Experimental Biology, University of Wroclaw, 6/8 Kanonia Str., 50-328 Wrockaw, E-mail: katarzyna.kabala@uwr.edu.pl

\section{HYDROGEN SULFIDE AS A REGULATORY MOLECULE IN PLANT CELLS}

\section{Summary}

For a long time, hydrogen sulfide has been known as strong toxin harmful to living organisms. Recent studies have shown the beneficial effect of low doses of $\mathrm{H}_{2} \mathrm{~S}$ on functioning of both animals and plants. It was also confirmed that $\mathrm{H}_{2} \mathrm{~S}$ acts as a signaling molecule similar to two other well-known gasotransmitters, nitric oxide and carbon monoxide. The enzymes responsible for $\mathrm{H}_{2} \mathrm{~S}$ generation have been identified in plant cells. These include desulfhydrases, located mainly in the cytosol, as well as sulfite reductase, present in chloroplasts, and mitochondrial $\beta$-cyanoalanine synthase. Numerous studies indicated that $\mathrm{H}_{2} \mathrm{~S}$ level increases significantly in plant tissues in response to unfavorable environmental conditions, such as salinity, heavy metals, drought, high and low temperature, suggesting its essential role in plant adaptation to abiotic stresses. I has been proposed that the main mechanism of $\mathrm{H}_{2} \mathrm{~S}$ action is the post-translational modification of reactive cysteine residues in proteins, called S-sulfhydration.

Key words: abiotic stress, desulfhydrases, hydrogen sulfide, signal transduction, S-sulfhydration 